\title{
Typology of Lingua-Geographical Terms of European Languages and Cultures (on the Sample of English, German, French and Tatar)
}

\author{
Rustam M. Fakhretdinov ${ }^{1}$ \\ ${ }^{1}$ Kazan (Volga Region) Federal University, Kazan, Russia \\ Correspondence: Rustam M. Fakhretdinov, Kazan (Volga Region) Federal University, 420008, Kazan, \\ Kremlyovskaya Street, 18, Russia. E-mail: roustam@mail.ru
}

Received: June 15, 2015 Accepted: June 24, 2015 Online Published: June 30, 2015

doi:10.5539/jsd.v8n7p9 URL: http://dx.doi.org/10.5539/jsd.v8n7p9

\begin{abstract}
The problem is seen acute, as there exists insufficient data on the typology of the French and Tatar languages. The article is aimed at comparing of the concept "the parts of the world" realization in European languages and Tatar, and proving the proximity of Tatar and French on the language level. The investigation results in the necessity of including the Tatar language into the family of European languages. Meanwhile, certain ways of enriching the vocabulary base of the Tatar language are offered, as well as an original way of the meaning differentiation of some lingua-geographical terms of Tatar on the French sample is put forward. The article material may be found fruitful by linguists while their writing on the typology of non-native languages. It can also be of high value for Russian-language and Turk-languages scientists who aim at enriching the vocabulary of their languages.
\end{abstract}

Keywords: typology, the French and Tatar languages, the concept "the sides of the world" and the dichotomy «кала - шәһәр» in European languages

\section{Introduction}

\subsection{Problem Acuteness}

Native language-oriented science on the turn of the XX century is characterized by summing up the achievements of the whole millennium period of science and language development and a scientific paradigm shift: from logical-and-grammatical and formally semantic directions to anthropology-centered linguistics (Valeyeva \& Gizatullina, 2013). An anthropological language-learning approach envisages a combination of a language mastering principle and a human being (Bikmayeva, 2007). The language is interpreted as an inevitable human medium, and a human becomes a human by means of the language (Ismagilova, 2009). Taking a cognitive-and-anthropological view on the language into account, the article dwells on - on the one hand - a lingua-geographical interpretation of Tatars' parts of the world in comparison with other European nations, and on the other hand - on characterizing an ideographic system of the "parts of the world" cognitive sphere as the basis of panoramic characteristics of the world-vision by various European ethnos-groups. It all aims at enriching the Tatar language vocabulary.

As long as the article is devoted to linguistic geography, it puts the French, Tatar and Russian languages under analysis, despite the fact that Tatar is not in the group of Indo-European languages - it belongs to the family of Altai-languages (Shilikhina, 2007). It is a scientific fact that geographically Tatarstan is located in Europe moreover, large Tatar communities keep their language in such European countries as Lithuania and Finland. The Republic of Tatarstan is documented in the Council of Europe and the Parliament Speaker of Tatarstan Farid Mukhametshin is a chairman of the Committee of little ethnoses of Europe.

\subsection{Explore Importance of the Problem}

The Tatar language inclusion into a family of European languages and cultures may be seen as paradoxal, however the comparison result may also turn out to be interesting. Every language scientist working on typologies of French and Tatar constantly comes across one and the same phenomenon of the parallel existing between these genealogically distant languages - this parallel may lie invisible up to a certain moment of time. In the article given we would like to draw your attention to some lingua-geographic terms which are diversely set in Tatar and French and single-viewed - in Russian (Khabibullina, 2012). 


\section{Methodological Framework}

Firstly, let us analyze common terminology of the parts of the world. In the French language - as well as in many other languages - words denoting the parts of the world are present in different notions which express the culture of the people living in this or that world side. In both Russian and Tatar there are four words. It seems to us somewhat illogical. "Vostok" (East) is an accurate and at the same time multi-content term which is denoted with a single word in the Russian language, although everyone should understand that a geographical term finds no accordance with a cultural image. Oriental culture is not the art of Russian people living far beyond the Urals, it is the world picture of the inhabitants of Middle-East republics located southwards, not eastwards in relation to Russia.

Accordingly, a Russian-speaker not well-acquainted with geography, may come across a misunderstanding of the terms "the Far East", "the Near East", "the Middle East" as long as only the first one is identical to its content. The last one stands for a number of Muslim countries located eastwards from the Mediterranean coastline and southwards from the Russian Federation. This variance appeared in the XV century when the young Russian state was expanding eastwards and collided - in the first turn - with Bulgarian khanate which was both geographically and culturally an absolutely oriental state. So the Russian state man of the time of the tsar Ivan the Terrible had a picture in his mind about a vast territory (including the Urals) with a developed Oriental Muslim culture, which population took Islam in the year of 922. Ideally, looking through modern linguistics, to avoid this misconception the modern Russian language should produce a special word for denoting the Muslim East. For instance, in French the geographical term "l'Est" is separated from the cultural term "l'Orient", despite the fact that Middle-East countries are really geographically located in the East. It does not possibly happen because of peculiarities of the Russian mentality. We can just feel sorry for the Tatars' forgetting such good notions as «Шәрык» and «Мәшрикъ» (Zeinullin, 1994), the presence of which makes the Tatar language native to a European notion "Orient". The copied-from-Russian terms «Якын Көнчыгыш» for the Near East and «Урта Көнчыгыш» for the Middle East should sound conflictive for Tatar native speakers. Therefore, as a pure native speaker, let me offer to fix the vocabulary norm of the Tatar language «Якын Шәрык» for the Near East and, accordingly, «Урта Шәрык» - for the Middle East. «Ерак Көнчыгыш» might be left for denoting the Far East. However, there are still vast territories of Eastern Asia from Japan to China, and their culture is also called "vostochnaya" (eastern, oriental) in the Russian language, though their culture differs from the culture of Muslim countries of the majority of Asian countries. To get rid of this cognitive dissonance let me offer the notion «Мәшрикъ» to denote "Vostok" (East) as the non-Muslim culture (the Buddhist culture in general) of foreign countries of the Far East including Korea and Indochina. Having supposed that analogically with the French language there should be a difference in geographical and culturological notions in the Tatar language in relation to the rest parts of the world, we pursued our research.

Likewise, geographical south in the French language has the notion "le Sud", whereas "the south of France" is referred to as "le Midi". In the Tatar language it is «көньяк» (geographical term), «жәнүб» и «кыйбла» (Ganiev, 1985), the sacred part for all Muslims owing to the location of the temple in Makkah, and all prayers of Islam-followers are directed southwards. Consequently, there should be a differentiation among the three terms made - like the one existing in the French language. It is my recommendation that the lexeme «көньяк» should be left as nominating the south as one of the geographical parts of the world. Its synonym «Жәнүб» might preferably consider the south of Russia (from the downflows of the Volga to Krasnodarski area) with the local folk culture; and the term «Кыйбла» could stand for the south as the territory and culture of Arabic countries of the Arabian peninsula. We could get away from uncomfortable expressions like "in the south of the South of Russia" in the case the forgotten vocabulary mentioned comes back to life. In Tatar it should sound like: «Жәнүбның көньягында».

Unquestionably, in relation to the notion of "North" the Tatar language wins in comparison with the French language: "le Nord" seems lonely in front of the Tatar notions «төньяк» and «Шималь». It obviously happens because of the lack of knowledge about the Northern people's culture - moreover, France is a pure southern country, geographically speaking. Unlike the Tatar ethnos which lives in the proximity with Northern nations. The Yakut language, for example, comes into the family of Turk languages, but on the other hand, it borders on the areal of Northern languages and tested their influence on it. For instance, under the influence of the grammar case system of the Evenki language, in the Yakut language nine cases have been formed, as long as there are six of them in the Turk group. From all European languages only Italian has a separate word for denoting the culture of the North - "settentrione", but for denoting the north of Italy. This noun can be found in French dictionaries as an archaic one: "septentrion". Both these notions date back to the Latin word "septemtrio", meaning seven stars of the Ursa Major constellation which could at all times define the north. However, the French language has 
the daughter-adjective "septentrional". In this case both terms "Шималь" and "septentrion" have an inactive status in both languages. Let us hope that the given article will make its modest contribution into enriching the two compared languages. It is quite obvious that both languages are falling into a deep dependence on the English language! Interestingly, a special lingua-cultural term for denoting the concept of "север" (north) which should have appeared in the Russian language a long time ago, is presented in the form of "северA". Doubtfully might it be considered as an independent term, it could rather be a plural form of the word form "север".

A geographical West in French is "l'Ouest", culturologically "l'Occident". Moreover, French poetry suggests "le ponant" and "le couchant" which are antonymous to "le levant", they mean «встающий» ("rising") or figuratively - «сторона встающего солнца» ("the part of the rising sun"). The latter has given name to a Near East country of the eastern Mediterranean, a French island in the Mediterranean sea, a region in Eastern Spain. It is also analogous to a German "Morgenland", which stands for "a morning country". Equally important, an inner structure of the above mentioned French lexeme is in close correlation with its Tatar analogues. The word "couchant" means «ложащийся» ("lying down") in French, meanwhile, metaphorically, it stands for «сторона света, где ложится спать солнце» ("the part of the world where the sun goes to bed"). In the Tatar language there exists a geographical term «көнбатыш» - "dipping into the dark" or into the world part where the sun "sinks". And for denoting the West as a cultural phenomenon we have found the forgotten word form «Гареп». In addition, there is one more Tatar word with Arabic background - «Мәгъриб» (Makhmutov, Khamzin \& Saifullin, 1993), but it cannot denote the whole West as the word was historically attached to its certain part. It is not by chance the countries of Magriba are called so - they are located westwards the Arabic world, they are French-speaking countries of north-western Africa: Mauritania, Morocco, Algeria and Tunis. Curiously, this very word "le Maghreb" is really wide-spread in European languages and denotes the common culture of Arabic countries of the Western Sahara.

\section{Results}

The above mentioned analogies underline a spiritual unity of the Tatar and French languages - through common vocabulary of Arabic background as well. We can present a table to give a vivid picture of the Tatar language being an organic part of the common European culturological paradigm of the four parts of the world, as the coordinate system for each nation matters a lot.

Table 1. Typology of lingua-geographical concepts of European languages and cultures on the sample of the Tatar, French, Italian, Spanish, Portuguese, English, German and Danish languages

\begin{tabular}{|c|c|c|c|c|c|c|c|c|}
\hline \multirow[t]{2}{*}{ Language } & \multicolumn{2}{|l|}{ North } & \multicolumn{2}{|l|}{ South } & \multicolumn{2}{|l|}{ West } & \multicolumn{2}{|l|}{ East } \\
\hline & geogr. & cultur. & geogr. & cultur. & geogr. & cultur. & geogr. & cultur. \\
\hline Tatar & Төньяк & шималь & көньяк & $\begin{array}{l}\text { кыйбла } \\
\text { жәнүб }\end{array}$ & көнбатыш & мәгъриб гареп & көнчыгыш & $\begin{array}{l}\text { шәрык } \\
\text { мәшрикъ }\end{array}$ \\
\hline French & nord & septentrion & sud & Midi & ouest & $\begin{array}{l}\text { occident } \\
\text { ponant } \\
\text { couchant }\end{array}$ & est & orient levant \\
\hline Italian & nord & settentrione & sud & $\begin{array}{l}\text { mezzogiorno } \\
\text { medidione }\end{array}$ & ovest & occidente & est & oriente \\
\hline Spanish & norte & & sur & mediodía & oeste & occidente & este & oriente \\
\hline Portug. & norte & & sul & meio-dia & oeste & ocidente & (l)este & levante \\
\hline English & North & & South & & West & Occident & East & Orient \\
\hline German & Nord & & Süden & & Westen & Abendland & Ost(en) & $\begin{array}{l}\text { Orient } \\
\text { Morgenland }\end{array}$ \\
\hline Danish & Nord & & syd & & vest & Vesten & Øst(en) & orient \\
\hline
\end{tabular}

As we can see, the majority of European languages have at least one cultural concept which comes in parallel with a geographical term «восток» (East). Besides, general Germanic languages have a culturological depiction of the West. In Romanic languages (located in the south of Europe territorially) the culturological parallelism is 
added when we speak about the South. Unlike the French, Italian and Tatar languages with an absolute dualism concerning the parts of the world. Analogous parallels which show the proximity of the Tatar language with European ones can be seen in investigating the concept «река» ("river"). Being indivisible in the Russian language, it is differentiated in the languages which are under analysis now: «елга» and «дарья» - in Tatar, "la rivière" and "le fleuve" - in French, "a stream" and "a river" - in English, "der Fluß" and "der Storm" - in German, etc. This dichotomy functions as «обычная река» ("an ordinary river"), running into another one, and «большая река» (“a big river"), flowing, as a rule, into the sea. But this investigation is beyond our article because of a natural limitation of our publication parameters.

\section{Discussions}

To confirm our ideas, we can give phraseological units with the above mentioned lingua-geographical terms as an example. In the Tatar language they are: "гарептән шәрыккә", “шәрыктән гарепкә" - from West to East, from East to West; i.e. «весь мир» ("the whole world"), including the cultural one as well. Or: "беребез мәшрикътә", "беребез мәгьриптә" - one (of us) is in the East, another one - in the West; i.e. "they are far from each other" (in the spiritual sense too). Or: "күңелемнең кыйбласы” (Isenbet, 1989) — "the light of my soul". Or: "Шималь йолдыз" - "the Polar star". The presence of these idioms can testify the fact that the found words have come into Tatar vocabulary and have become an integral part of the Tatar people's soul.

A similar situation takes place in the French language: "Église d'Occident" - "католическая церковь" (Catholic church) and, accordingly, "l'Église d'Orient" - “православная церковь” (Orthodox church), “а l'empire d'Orient" - "Византийская империя" (the Vizanty empire). And one more idiom with a cultural-and-geographical component: "Échelles du Levant" - "ladders leading to the East", a figurative name of cities and ports of the Mediterranean area which are open for trading among Europeans, the Near East and the Middle East inhabitants.

This very phenomenon of relative-to-each-other words with similar meaning we can observe in the term «Город» ("city"), which is divided into two concepts in European languages: "la ville" and "la cite" - in French, "city" and "town" - in English, "ciudad" and "villa" - in Spanish, "by" and "stad" - in Danish, and, finally, «шәһәр и кала» - in Tatar. Unlike the French and Europeans who differentiate between a small town and a big city, the Tatars - under the influence of the Russian language - have stopped this distinguishing. Notably, there is even a phraseological unit with these inter-changeable components: «Шəһəp (кала) алган кебек» («как будто город взял» - "as if I have conquered the city"), i.e. «ходить с торжествующим видом» ("walk with an expression of a winner on the face"). To give more emotions to the idiom, one could suggest the following translation variant: “как будто Берлин взял!” (“as if I have conquered Berlin!”). The idioms themselves should be divided in accordance with the law of sinharmonism which is characteristic of all Turk languages: «шәһəр алган шикелле» and «кала алган кебек». Interestingly, French phraseology has an analogous expression: "avoir ville gagnée" (Retzker, 1963) - «завоевать город» (“conquor the city") and metaphorically stands for: «восторжествовать» ("prevail"). "Cité" is a hyponym in relation to its hyperonym "la ville" and means its part - as a rule - the most ancient one.

Definitely, the Tatar language must have the same differentiation. That is why we can recommend to leave the word «шәһәр» for denoting any city, and the word «кала» - for its central historical part. Therefore, we can get rid of the cognitive dissonance which can turn up with every Tatar native speaker when naming «Иске Татар бистәсе» - a present-day copy from the Russian concept «Старо-Татарская слобода» (“The Old-time Tatar Sloboda / Village"). The term may provoke thinking that a historical city-centre turns out to be the suburbs. Moreover, we should not forget about a powerful law of economizing a language, according to which the historical centre of Kazan might be referred to shortly and clearly as «Казан каласы» in difference from «Казан шəhəpe» for denoting «big» Kazan with its sleeping, industrial districts and countryside. Eventually, a special sense will be given to the word form «кала урамы» - it might be understood as charming pre-revolutionary reconstructed streets which appear in large numbers in the modern Kazan city-centre. And simple city streets can be referred to as «шәһәр урамы». Emphatically, we can again attract Tatar phraseology as a reflection of deep vocabulary layers of the Tatar people. Take the case of a huge cottage which is referred to as «кала суккан кебек» - «крепость» (“а castle"). For the simple reason that the word «кала» was associated with a castle in ancient times, the castle which was actually the city of that time. With time cities grew bigger far beyond the limits of castle walls: «кала» was expanding towards the term «шәһәр». In some Turk languages there is still this meaning: "kala" - in Turkmenian, "kale" - «крепость» (“a castle") in Turkish. The gates leading to the city-castle in a later peaceful time were always open - therefore, one more Tatar phraseologism appeared: "кала капкасы" - "городские" ворота ("city gates") (about a door open-wide). City-castles were fenced with a castle wall - i.e., the city territory was rigidly limited and could not be big. The remains of such a castle wall can be 
observed in Pskov where they form a natural borderline of the historical city-centre. There it is called «городище» ("the big city"), it proves that the Russian language also has a potential for forming the given lexical dichotomy, although the word does not find its wide-spreading - possibly, due to the lack of independence of the existing word form «город» (“city").

In the Tatar language we can also find a couple of phraseological units with the following synonyms: «кала күмәче» - "white bread", "du pain blanc" - in French and «шәһәр икмәге килешкән» which is rendered as «городской хлеб пошёл на пользу» ("the city bread is doing good"), and figuratively - «жизнь в городе пошла на пользу» ("the city life is bringing good"). In the Russian language there is an idiom «понравилось жить на барских харчах» (with an approximate translation as "you have liked living (and eating) like the king of the world") because in old times when bondmen-peasants ("krepostniye") and their hosts left for the city for the winter-period, this fact could cause jealousy with peasants who were left in the village.

In other phraseological units the word «шәhəр» is used in the meaning of "the whole city" («целого города»): «шәһәр кыдыра чыгу» is rendered as «прочесать город» ("run through the city") or, metaphorically, «по-быстрому ознакомиться с городом» ("quickly get acquainted with a city"), and is not by chance the word «шәһəр» is used because we can «прочесать» ("go through"), as a rule, vast spaces like the forest, suburbs, etc. Remarkably, the French language also gives an absolutely identical in sense idiom "faire toute la ville", which stands for «сделать весь город» ("to make the whole city").

Following this further, «шәһәрен бөрергә» is translated as «скрутить город», i.e., «взять приступом» ("conquer the city") - "prendre d'assaut" in French. We can suppose that initially both in the French and Russian languages this set-expression was not a phraseological unit, as it was used with its direct meaning - in relation to cities. And only when later this phraseological unit acquired the meaning referring to our fair ladies, they became idioms in all European languages.

Undeniably, not always the analyzed component «город» is kept in compared idioms even mentally. For instance, the proverb «калага урыс керде-чыкты» means «в город русский зашёл-вышел» ("into the city the Russian came in-went out") with the sense of the thing ridiculous: somebody came in or went out. In the Russian language there is a proverb «бабушка надвое сказала», and in French - "je n'en mettrais pas ma main au feu" (meaning «я бы не положил за это руку в огонь» - "I would put my hand into the fire for this"). The latter proverb dates back to the time when an inquired person could be able to put his hand over the fire to prove his being true.

Another Tatar proverb «каладан салага печән ташырга» - «таскать сено из города в село» (“take hey from the city into the village") has acquired its own national meaning - «ездить в Тулу со своим самоваром» ("go to Tula with your own samovar"). The problem is it cannot be rendered properly into other European languages owing to its originality. We can try to translate it - knowing its Tatar prototype - using a French analogue "porter de l'eau à la rivière", which stands for «носить воду в реку» ("carrying water into the river"), and which is rendered as «носить воду решетом» (“carry water with a sieve").

A phraseological unit "les maisons empêchent de voir la ville" - «дома мешают видеть город» ("houses do not give a chance of seeing the city") has been transformed into «за деревьями лесу не видать» ("one cannot see a forest behind the trees") because of the Russian and Tatar people being close to nature. In Tatar it sounds like «агачын күреп урманын күрмәскә». Accordingly, the next urban-based idiom "les villes en sont pavées" «этим города вымощены» (approximate: "all city roads are covered with it") both in Russian and Tatar is re-organized into naturalistic idioms «хоть пруд пруди» and «буа буарлык». And the proverb "ville prise, château rendu" - «если город взят, замок тоже сдан» ("if the city is conquered, the lock is also conquered") equals to «лес рубят - щепки летят» — «ат аунаган жирдә төк кала» in Tatar which word-in-word meaning is «где конь валяется, там и шерсть остаётся» ("where the horse lies, there is its fur"). Or a French saying "être fable de toute la ville" - «быть героем анекдотов для всего города» ("to be a matter of laughter for all the city"), i.e., an all-round man of tricks (in Tatar - «кеше көлкесенә калырга»). Or: "avoir ménage en ville" «иметь хозяйство в городе» was obviously said about wealthy bachelors living in the countryside and having a woman in the nearest town to host the household, which was later extrapolated into «содержать любовницу» ("having and financially supporting a mistress"). In the Tatar language there is no double meaning: «сөяркә тотырга», in French - "le trompette de ville" («городской трубач» - "a city trumpeter") had an initial metonymic meaning of «глашатай» (“a herald, a messenger"), because before calling out a law he attracted citizens' attention with the sounds of his trumpet. However, with the disappearance of this position, this word acquired the meaning of a chatter-box, gossiper - «агач мылтык» in Tatar, which stands for «деревянное 
ружьё» (“a wooden gun") as an allegory of something not really serious - something we should not be afraid of, but should listen to.

There are some French idioms with no analogues in Tatar, because they reflect an absolutely strange for the communal Tatar people reality, for instance, "maison de ville" - "дом города" ("the house of the city") - it is a town hall. Or "le premier élu de la cité” - «первый избранник города» - “а mayor”. Unfortunately, the Tatar language has not got many figurative names of famous cities, such as "la Ville lumière" — "город-светоч", “enlighted city" (Paris); "la Ville éternelle” — “Вечный город” (Rome), or "ville aux sept collines” - “город на семи холмах" (“the city on seven hills"); and even ”la cité sainte/ céleste” — “святой/ райский город” (“а saint paradise city") (Jerusalem) - despite the fact that the latter is sacred for Muslims as well.

In rare cases an urban component is equally present in all languages under our analysis, for instance, the saying “avoir un œil aux champs et l'autre à la ville” - «один глаз - в поля, а другой - в город» (“one eye - to the fields, another one - to the city") has metaphorically acquired two meanings: 1) to be cautious, considerate, be on alert - «сак булырга» in Tatar; 2) to be squint-eyed, «кылый (чалыш) күзле» in Tatar. A similar French expression "être aux champs et à la ville" - «быть в полях и в городе» ("to be out in the fields and in the city") logically means «жить на самом краю города» ("living on the edge of the town"), i.e., «иметь дом с садом» ("have a house and a garden"). The Tatar «шәһәрнең кырыенда (читендә) яшәргә» can hardly be named a phraseological unit because it does not have a parabolic undertone.

And finally, the last samples of synonymous phraseological units: "fille et ville qui parlementent sont à moitié rendues" - “девушкой и городом, которые вступили в переговоры, овладеть нетрудно” (“a girl and a city that are in the process of negotiation, are easy to win"); and "ville qui capitule, ville à demi rendue" - "кто слушает предложение о сдаче, тот готов на него согласиться" ("the one who is listening to an offer about the change, is ready to agree to it”), «кыз hәм шәһәр сөйләшү башланган - яртылашка бирелгән» - in Tatar. We can hardly come across a proverb of the kind in Russian. So, we can see that the components "la ville" and «шәһәр» are present in idiomatic treasury of the French and Tatar languages in a much wider range than their hyponyms "la cite" and «кала», which indirectly confirms a parallelism of their usage.

\section{Conclusion}

It is beyond any doubt that every language has its own unique features which differ it from other languages. This set of features is thought to be non-occasional. We can claim that in each case the set of features presents a certain stable system. Consequently, a stable unity of the leading language features, interacting with each other, is a language type. The presence or absence of one sign defines the presence or absence of the other sign or a row of signs. In the given article we have demonstrated a close proximity of the Tatar language to French, rather than Russian. Unfortunately, the limits of this scientific article give no possibility to deepen our lingua-geographical research. We can suppose that a comparative analysis of adjectives, adverbs and verbs, etymologically connected with the nouns having been analyzed in our research, could give a no less interesting result.

\section{Recommendations}

In conclusion, we would like to express hope that the analogies given in this research will not stay theoretical, that they will enrich the Tatar language with a prospect of taking a worthy place in the friendly family of European languages. The materials of this article could be of valuable for philologists, carrying out research on the typology of non-native languages.

\section{Acknowledgement}

The work is performed according to the Russian Government Program of Competitive Growth of Kazan Federal University.

\section{References}

Bikmaeva, L. U. (2007). Lingvogeograficheskaya interpretatziya foneticheskih I leksicheskih osobennostei sterlitamakskogo govora misharskogo dialekta tatarskogo (v sravnenii $s$ drugimi govorami Zapadnopriural'skogo areala). (Unpublished master's thesis). Kazan: IYLI.

Ganiev, F. A. (1985). Russko-tatarstki slovar. Moscow: Russki yazyk.

Isenbet, H. (1989). Tatar telenen frazeologic suzlege. Kazan: Tatarstan.

Ismagilova, D. B. (2009). Konversionnoye slovoobrazovaniye vo frantzuzskom I tatarskom yazykah. Kazan: Poznaniye. 
Khabibullina, E. H. (2012). Tipologiya abstraktnyh substantov mnozhestvennogo chisla (na materiale frantzuzskogo, russkogo i tatarskogo yazykov). Aktual'nye problem sovremennoy lingvistiki. Kazan: KFU.

Makhmutov, M. I., Khamzin, K. Z., \& Saifullin, G. Sh. (1993). .Arabsko-tatarsko-russki slovar' zaimstvovaniy. Kazan: Iman.

Retzker, Ya. I. (1963). Frantzuzsko-russkiy frazeologicheskiy slovar'. Moscow: Gosudarstvennoe izdatel'stvo natzional'nyh i inostrannyh slovarei.

Shilikhina, K. M. (2007). Osnovy lingvisticheskoy tipologii: Uchebno-metodicheskoye posobiye. Voronezh: IPTZ VGU.

Valeeva, A. F., \& Gizatullina, A. K. (2013). Emotzional'no-ekspressivniye predlozheniya v tatarskom I frantzuzskom yazykah kak resul'tat kompressii sintaksicheskoi struktury (emotzii I ih priroda). Fundamental'niye issledovaniya KFU, 11-4.

Zeinullin, Zh. G. (1994). Sheryk alynmalary suzlege. Kazan: Magarif.

\section{Copyrights}

Copyright for this article is retained by the author(s), with first publication rights granted to the journal.

This is an open-access article distributed under the terms and conditions of the Creative Commons Attribution license (http://creativecommons.org/licenses/by/3.0/). 